Please do not remove this page

RMIT

UNIVERSITY

\title{
Whose job is that? Saving the biosphere starts at work
}

Brennan, Linda-Marie; Binney, Wayne; Hall, John; Hall, Michelle

https://researchrepository.rmit.edu.au/esploro/outputs/9921862526501341/filesAndLinks?institution=61RMIT_INST\&index=null

Brennan, L.-M., Binney, W., Hall, J., \& Hall, M. (2015). Whose job is that? Saving the biosphere starts at work. Journal of Nonprofit and Public Sector Marketing, 27(3), 307-330.

https://doi.org/10.1080/10495142.2015.1053348

Document Version: Accepted Manuscript

Published Version: https://doi.org/10.1080/10495142.2015.1053348

Repository homepage: https://researchrepository.rmit.edu.au

(C) Taylor \& Francis Group, LLC

Downloaded On 2023/04/26 21:44:11 +1000

Please do not remove this page 
Thank you for downloading this document from the RMIT Research Repository.

The RMIT Research Repository is an open access database showcasing the research outputs of RMIT University researchers.

RMIT Research Repository: http://researchbank.rmit.edu.au/

\section{Citation:}

Brennan, L, Binney, W, Hall, J and Hall, M 2015, 'Whose job is that? Saving the biosphere starts at work', Journal of Nonprofit and Public Sector Marketing, vol. 27, pp. 307-330

See this record in the RMIT Research Repository at:

https://researchbank.rmit.edu.au/view/rmit:33070

Version: Accepted Manuscript

Copyright Statement: (c) Taylor \& Francis Group, LLC

Link to Published Version:

http://dx.doi.org/10.1080/10495142.2015.1053348

\section{PLEASE DO NOT REMOVE THIS PAGE}




\section{Saving the biosphere starts at work. ${ }^{1}$}

Professor Linda Brennan, * (corresponding author)

RMIT University, School of Media and Communication, Bldg 9, Level 5, Room 28

124 LaTrobe Street

Melbourne 3000

GPO Box 2476 Melbourne, Victoria, Australia, 3001.

+61399252842

Linda.brennan@rmit.edu.au

Associate Professor Wayne Binney, Department of Marketing, Faculty of Business and Law Deakin University, 70 Elgar Rd

Burwood

Victoria, 3125 Australia

+61392445540

wayne.binney@deakin.edu.au

Professor John Hall, Deakin University, Australia

Department of Marketing, Faculty of Business and Law

Deakin University,

70 Elgar Rd

Burwood

Victoria, 3125 Australia

+61392445054

john.hall@deakin.edu.au

Dr Michelle Hall, Deakin University Australia

Department of Marketing, Faculty of Business and Law

Deakin University,

70 Elgar Rd

Burwood

Victoria, 3125 Australia

+61392445540

michelle@questioning.com.au

1 This paper is an early version of a paper that eventually appears as L. Brennan, W. Binney, J. Hall, M. Hall, Whose Job Is That? Saving the Biosphere Starts at Work, Journal of Nonprofit \& Public Sector Marketing, 27 (2015) 307-330. 


\title{
Saving the biosphere starts at work.
}

\begin{abstract}
Research on sustainability programs within universities consistently emphasizes that sustainability requires a combination of factors so as to move beyond the significant, but often limited activities such as recycling and energy saving, to achieve systemic implementation. This study applied Brennan and Binney’s 9Ps Social Marketing Framework to investigate sustainability practices of member universities of ACTS (Australian Campuses Towards Sustainability). A questionnaire based on qualitative research obtained data from 25 of the 27 member universities. Data analysis including descriptive statistics, ANOVA, factor analysis and gap analysis was used to determine the relationships between 'importance' and 'performance' of the behaviours under investigation.
\end{abstract}

Over the 9Ps, 27 items were used to identify important aspects of environmental sustainability and of these which were being applied. It was generally found that while many universities had policies in place these were not being implemented and practices maintained. Significant differences were found between the aspects perceived to be important by the 'expert' respondents and those actually being performed by staff. Management could use these findings to address the gap between importance and performance of sustainable practices. Further study to identify the specific barriers to widespread adoption of these sustainable initiatives is suggested. 


\section{Introduction: Universities in relation to sustainability}

It is broadly acknowledged that universities can play a leadership role in relation to sustainability; through research, the inclusion of sustainability within the curriculum, and through institutional implementation (Sawang \& Kivits, 2014). Literature and research on sustainability programs within universities consistently emphasizes that sustainability requires a combination of grass roots action and strong leadership, so as to move beyond the significant, but often limited activities such as encouraging recycling and energy saving, to achieve systemic implementation (Krizek, Newport, White, \& Townsend, 2012). The aim of this study is to investigate how universities are planning and systematically embedding sustainability into the operation of their campuses.

\section{Sustainability in higher education settings}

The role of universities in fostering sustainability has been the subject of much attention since the global energy crisis in the early 1970s (Wilson Jr, 1973). Universities have a responsibility to contribute to the debate and there have been a number of international declarations and initiatives. These have included the Talloires Declaration of University Leaders for a Sustainable Future of 1990 (Tallories, 1990); the Halifax Action Plan for Universities of 1991 (Halifax, 1991) and the Kyoto Declaration of the International Association of Universities of 1993 (Kyoto, 1993). Following these there was also a declaration of the United Nations Decade of Education for Sustainable Development, starting in 2005 (United Nations, 2005). However as researchers have noted, being a signatory of such declarations is no guarantee of action, and has been associated with 'green washing' (Chambers, 2009; Clugston \& Calder, 2000; Wright, 2002). Furthermore, these documents mostly offer guidelines rather than prescriptions for application on an operational level (Shriberg, 2002). Importantly, while 
proclaiming support, there is no clear link between the declarations and any individual action by Higher Education Institutions (HEIs) beyond the creation of a plan. In support of implementing sustainability in HEIs, several organisations have been established internationally, including the Association of University Leader for a Sustainable Future (ULSF), the Environmental Association for Universities and Colleges (EAUC) in the United Kingdom, the Association for the Advancement of Sustainability in Higher Education (AASHE), in the United States, and the Australasian Campuses Towards Sustainability (ACTS) in Australia and New Zealand. These organisations primarily provide resources, developmental and networking opportunities for member institutions, as well as represent universities at international meetings such as the Rio +20 conference. These organisations are indicative of the efforts taking place across the globe in educating those who will contribute to saving the biosphere; be that through research efforts, leading businesses or applying their learning to the issues and problems that are 'sustainability' in all its forms.

\section{Barriers and opportunities}

It has been argued that the nature of universities themselves can act as a barrier to the broad implementation of environmental sustainability measures (Hoover \& Harder, 2014). The most commonly raised barrier is the organisational structure of the university, where the separate nature of faculties and facilities can lead to diffuse power structures that may work against whole-of-university measures (Sharp, 2002). This can prevent grass roots initiatives from gaining broad acceptance (Posner \& Stuart, 2013). It also has implications for top down leadership, and underlies arguments for the value of declarations and organisational affiliations described above (Lee, Barker, \& Mouasher, 2013; Moganadas, Corral-Verdugo, \& Ramanathan, 2013). 
In addition, the role of the university as a site of intellectual freedom and knowledge generation is also viewed as a potential barrier to the adoption of a mission of sustainability (Clugston, 2000; Djordjevic \& Cotton, 2011; Orr, 2000; Sharp, 2002). This has been related both to the ways that existing academic paradigms may limit consideration of environmental challenges (Ralph \& Stubbs, 2014), as well as the potential for sustainability as an overarching vision to itself be seen as an ideology that constrains academic freedom (Sylvestre, McNeil, \& Wright, 2013). Despite the complexity, researchers consistently emphasise the benefits for, and moral responsibilities of, universities to embrace sustainability. These include the functional benefits of cost (Beattie, 2014; Bilodeau, Podger, \& Abd-El-Aziz, 2014) and operational efficiencies (Spira, Tappeser, \& Meyer, 2013), and the potential for a competitive advantage as a 'green' campus' (Dobson, Quilley, \& Young, 2010). The integration of sustainability is also proposed as a means of uniting disparate units within the organisation under a common agenda and fostering communication and coordination between both internal and external stakeholders (Krizek et al., 2012; Leal Filho, 2009a). The moral responsibility for universities to lead measures of sustainability is strongly indicated in Wright, (2010), who believes that university leaders are more likely to agree on broad policy roles than to focus on specific ways this may occur, such as, through research, policy development or implementation on campus. Again, there is a disconnect between the espoused philosophy of sustaining the biosphere and any potential to take action (Jones, 2012; Lee et al., 2013).

\section{Research on sustainability in higher education}

The ways and means of implementing sustainability measures within the university vary significantly across campuses and individuals. This is unsurprising given the breadth of the topic, the ongoing uncertainty that surrounds global commitment to issues of sustainability, and 
university specific barriers to implementation such as those described by researchers such as Karlin, Davis and Matthew (2013), Benjamin (2013) or Radford (2012). Research on sustainability within universities has been dominated by descriptive case studies of single campus programs. This includes detailed examples of how recycling campaigns, energy saving measures, car pooling, water conservation, green building designs and student training programs have been implemented within different universities (see for example the edited volumes Leal Filho, 2000, 2009b; Leal Filho \& Carpenter, 2006). Whilst this work has been criticized as being atheoretical, reports of 'this is what happens in my institution' (Krizek et al., 2012; Wright, 2010), as Sharp (2002) has noted, lessons from isolated or small scale efforts to implement sustainability programs can play an important role in informing processes of systemic transformation.

The dominance of case specific studies makes sense when we consider, as per Krizek et al. (2012) that the implementation of sustainability measures within universities can be seen to occur in four phases. The first is of grassroots programs, such as recycling. Grassroots programs are implemented on a small scale and are designed to enable and empower individuals within their micro-social system to act and to take action (Brennan, Binney, Parker, Aleti Watne, \& Nguyen, 2014). The second phase identified by Krizek is when campus leadership recognizes the value of such activities, in particular in their ability to provide cost savings and enhance efficiency, or the reputation and branding of the university. This phase allows for meso-level participants in the social system to engage in the interactions needed to embed sustainability in their practices (Cebrián, Grace, \& Humphris, 2013). The third phase of implementation posited by Krizek involves the promotion of a vision of sustainability by university management, and attempts to implement university wide policies. It is at this stage that organisational barriers may 
become most apparent, such as entrenched attitudes within different faculties and facilities, or from established grass roots campaigns. The final stage is the fully self-actualized and integrated campus community where sustainability is embedded across the university as a uniting principle and vision. In referring to this stage as the 'nirvana position' Krizek et al., (2012) neatly summarise what much other research also argues; that the barriers faced in phase three are significant and that the ideal of a university in which sustainability operates as a core integrating value is more of a position to aim for than one that is likely to be achieved. Partially this is to do with the tradeoffs between social and environmental enhancement activities and their associated financial costs.

In a similar staged assessment of university implementation of sustainability, Leal Filho (2009a) suggests that up to $10 \%$ of universities, mostly in Western countries, have reached a level of implementation where principles of sustainable development are widely understood, there are significant efforts toward promoting sustainability through programs, that are supported by long term commitments though policy, certification, oversight by senior staff and centrally funded projects. This implies however that $90 \%$ of universities worldwide have not progressed beyond grassroots campaigns or are still facing considerable internal barriers to systemic implementation. What appears to be occurring is that there is both top-down and bottom-up will to invest in saving the biosphere but the pragmatic issues involved with financing sustainability programs in a sector that is fairly constantly 'cash-strapped' can be overwhelming. It is not a simple matter to choose between a library and a green waste facility. What is needed is a method to examine the connections between the various levels of the university. That is, the connections between the policies and the participants in the meso and micro systems that make up the community of practice and through whom sustainability programs will be implemented. Or to be 
more specific, the gap between the planned activities and what is is being sytematically implemented requires investigation.

\section{Recommendations for systemic implementation}

What existing research most clearly demonstrates is the difficulties faced by universities in progressing from single issue programs to a broad integration of sustainability as a guiding principle and vision. This is despite a consistent range of recommendations within the literature regarding the ways to approach this task. A suggested approach to investigate these recommendations is by using the behavioural ecological framework developed by Hovell, Walhgren and Gerhman (2002). Actors in each of the levels are defined as operating in social systems that are influenced by each other. This is illustrated in Figure 1. The Behavioural Ecological Model proposes that individuals operate in an ecological system incorporating behaviours at four main levels. The levels are that of the society, followed by community, then the local level and finally the individual level. The individual is influenced by behaviours from other levels, in addition to their own social setting and personal characteristics. The influence is bi-directional with interconnections between the levels. Hovell and Hughes (2009) call this interlocking behaviour in the social setting; meaning that behaviours in each level influence other levels. Thus, a public policy directive - community level - has the potential to influence social mores over time (social/cultural level) as well as the local level institutions that influence behaviours of the individual. 


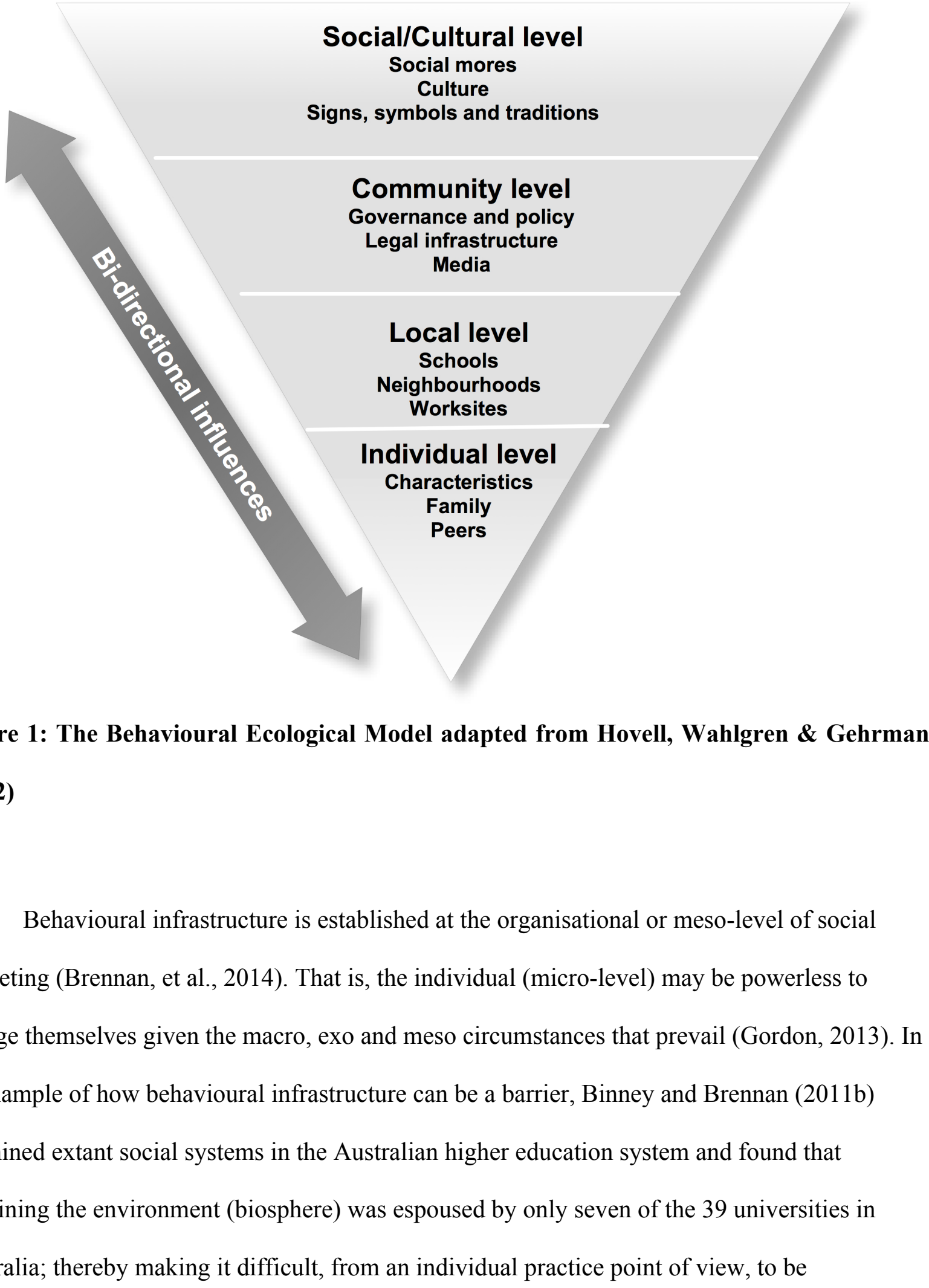

Australia; thereby making it difficult, from an individual practice point of view, to be 
sustainable. They proposed a framework for organisational infrastructure that would embed sustainability within the social system (in this case the university). This is illustrated in Figure 2.

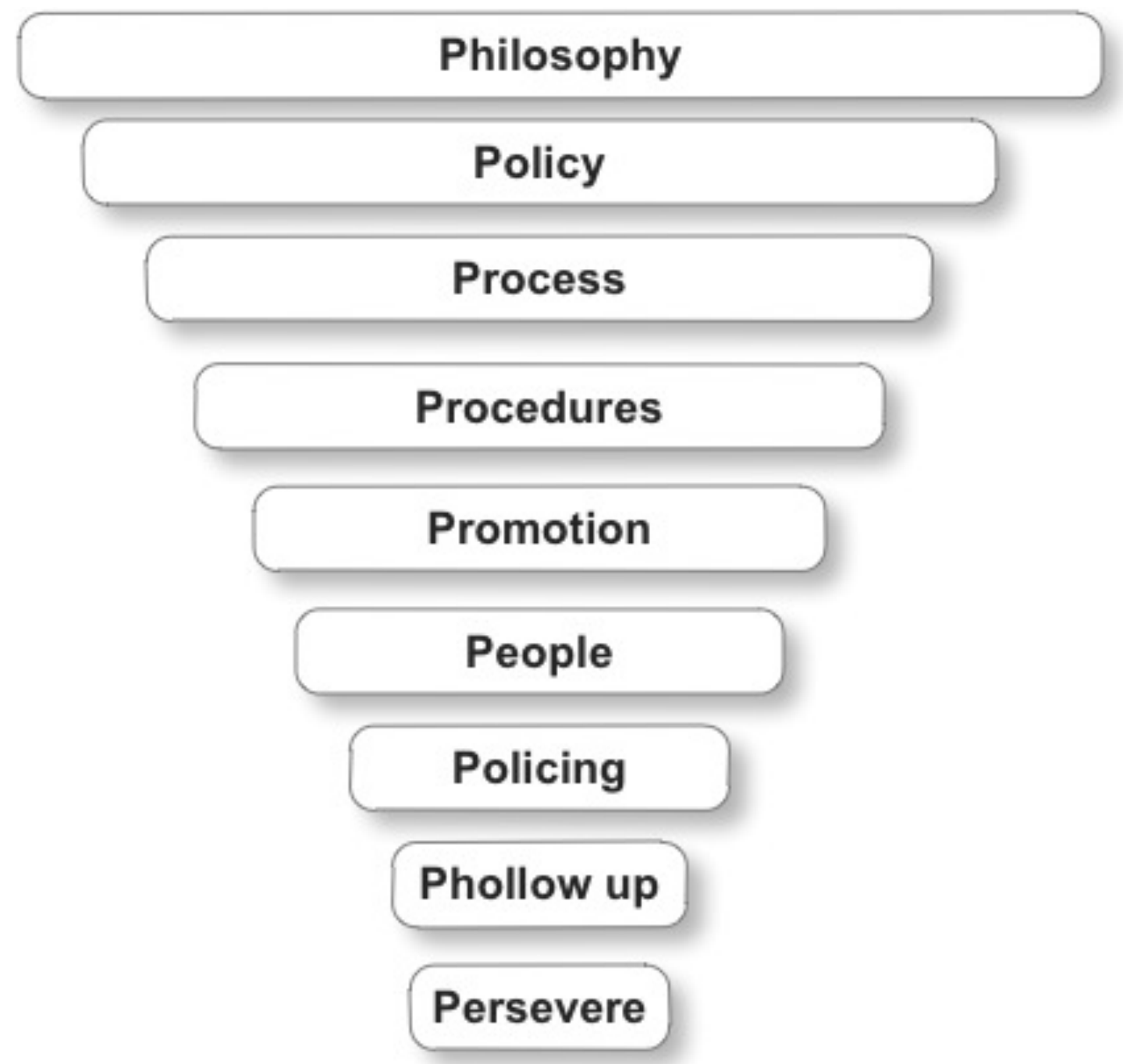

Figure 2: The 9Ps Model of Organisational Sustainability

The underlying premise is that all these elements must be aligned for an individual to be persuaded to participate in saving the biosphere. There should be an overarching philosophy; a clear statement of policy - transparent and articulated in terms the individual can engage with; a meso-level process by which sustainability can be managed; local procedures that consider the 
micro-level requirements of the individual within the behavioural setting; promotion of the issue (including related processes and procedures); advocacy and championship within the organisational context (people); there should be a system that provides for observations of behaviours and alerts when 'breaches' occur so that there are social consequences associated with unsustainable behaviours (policing); then, as with all things behaviour change, following up (phollow up) and perseverance are required for maintained positive change. Table 1 categorises the barriers and facilitators outlined previously in terms of the Nine-Ps framework of Brennan and Binney (2011a). 
Table 1: The 9Ps framework for environmental action in universities

\begin{tabular}{|c|c|c|c|c|}
\hline Element & Description & Item & Suggestions & Authority \\
\hline Philosophy & $\begin{array}{l}\text { The core set of beliefs guiding } \\
\text { the behaviors of the university }\end{array}$ & $\begin{array}{l}1.2 \\
1.3 \\
1.4 \\
\end{array}$ & $\begin{array}{l}\begin{array}{l}\text { Institutional mission } \\
\text { clearly includes } \\
\text { sustainability }\end{array} \\
\text { Written statements of } \\
\text { commitment to } \\
\text { sustainability } \\
\text { Funding provided for } \\
\text { sustainability initiatives } \\
\text { Fostering innovative and } \\
\text { creative environment }\end{array}$ & $\begin{array}{l}\text { Clugston \& } \\
\text { Calder } \\
(2000) \\
\text { Leal Filho } \\
(2009 a) \\
\text { Krizek et el., } \\
(2012)\end{array}$ \\
\hline Policy & $\begin{array}{l}\text { A policy is a statement of } \\
\text { principles to guide decision- } \\
\text { making. A policy is a } \\
\text { statement of intent and is } \\
\text { implemented using a process } \\
\text { or procedure. }\end{array}$ & $\begin{array}{l}2.1 \\
2.2 \\
2.3\end{array}$ & $\begin{array}{l}\text { Structure and planning } \\
\text { include sustainability } \\
\text { Management support for } \\
\text { sustainability } \\
\text { Written policies and } \\
\text { action plans }\end{array}$ & $\begin{array}{l}\text { Clugston \& } \\
\text { Calder, } \\
\text { (2000) } \\
\text { Sharp (2002) } \\
\text { Leal Filho } \\
\text { (2009a) }\end{array}$ \\
\hline Process & $\begin{array}{l}\text { A business process is a } \\
\text { collection of related activities } \\
\text { that are designed to achieve a } \\
\text { specific goal }\end{array}$ & 3.2 & $\begin{array}{l}\text { Design operations so that } \\
\text { sustainability can be } \\
\text { practiced } \\
\text { Allow for divergent } \\
\text { innovation and risk } \\
\text { taking }\end{array}$ & $\begin{array}{l}\text { Clugston \& } \\
\text { Calder } \\
(2000) \\
\text { Gough \& } \\
\text { Scott (2007) } \\
\text { Sharp (2002) }\end{array}$ \\
\hline Procedures & $\begin{array}{l}\text { Procedures are detailed written } \\
\text { instructions that allow people } \\
\text { to understand what they need } \\
\text { to do in relation to business } \\
\text { processes }\end{array}$ & 4.1 & $\begin{array}{l}\text { Effective coordination of } \\
\text { activities and clearly } \\
\text { detailed roles and } \\
\text { responsibilities }\end{array}$ & $\begin{array}{l}\text { Sharp (2002) } \\
\text { Krizek, et al. } \\
\text { (2012) }\end{array}$ \\
\hline Promotion & $\begin{array}{l}\text { Promotion is the } \\
\text { communication of }\end{array}$ & $\begin{array}{l}5.1 \\
5.2 \\
5.3 \\
5.4 \\
\end{array}$ & $\begin{array}{l}\text { Communicate the } \\
\text { philosophy to all within } \\
\text { the institution } \\
\text { Sustainability included } \\
\text { in all curriculum and } \\
\text { research } \\
\text { Look to professional } \\
\text { associations for support }\end{array}$ & $\begin{array}{l}\text { Krizek, et al. } \\
(2012) \\
\text { Clugston \& } \\
\text { Calder } \\
(2000) \\
\text { Gough \& } \\
\text { Scott (2007) }\end{array}$ \\
\hline
\end{tabular}




\begin{tabular}{|c|c|c|c|c|}
\hline Element & Description & Item & Suggestions & Authority \\
\hline People & $\begin{array}{l}\text { People are the individuals and } \\
\text { micro-level teams and work } \\
\text { groups that participate in } \\
\text { sustainability }\end{array}$ & $\begin{array}{l}6.2 \\
6.3 \\
6.4 \\
6.5 \\
6.6 \\
\end{array}$ & $\begin{array}{l}\text { Connective middle } \\
\text { management and support } \\
\text { for people } \\
\text { Partnerships between } \\
\text { stakeholders } \\
\text { Mobilizing people at } \\
\text { home and work } \\
\text { Training and } \\
\text { development } \\
\text { opportunities } \\
\text { Rewards and incentives } \\
\text { schemes } \\
\text { Maximize face to face } \\
\text { communication }\end{array}$ & $\begin{array}{l}\text { Gough \& } \\
\text { Scott (2007) } \\
\text { Sharp (2002) } \\
\text { Leal Fihlo } \\
\text { (2009a) } \\
\text { Clugston \& } \\
\text { Calder } \\
\text { (2000) } \\
\text { Gough \& } \\
\text { Scott (2007) } \\
\text { Krizek et al., } \\
(2012)\end{array}$ \\
\hline Policing & $\begin{array}{l}\text { Policing is the assessment, } \\
\text { monitoring and reporting of } \\
\text { results of sustainability } \\
\text { activities }\end{array}$ & 7.1 & $\begin{array}{l}\text { Sustainable forms of } \\
\text { assessment } \\
\begin{array}{l}\text { Measureable goals and } \\
\text { objectives }\end{array}\end{array}$ & $\begin{array}{l}\text { Gough \& } \\
\text { Scott (2007) } \\
\text { Krizek et al., } \\
(2012)\end{array}$ \\
\hline Phollow up & $\begin{array}{l}\text { Phollow up is what happens } \\
\text { after reporting. It encompasses } \\
\text { actions to remediate, enhance } \\
\text { and improve subsequent } \\
\text { undertakings }\end{array}$ & 8.1 & $\begin{array}{l}\text { Continuous improvement } \\
\text { and organizational } \\
\text { learning }\end{array}$ & Sharp (2002) \\
\hline Perseverance & $\begin{array}{l}\text { Perseverance is when you } \\
\text { continue to with the course of } \\
\text { action regardless of } \\
\text { discouragement; especially in } \\
\text { taking a long term perspective } \\
\text { of success }\end{array}$ & 9.1 & $\begin{array}{l}\text { Make mistakes and } \\
\text { continue anyway }\end{array}$ & Sharp (2002) \\
\hline
\end{tabular}

Some attempts have been made to develop models to assist universities to analyse and plan their sustainability activities. Associations such as the ULSF, the United State's National Wildlife Federation, the Forum for the Future's Higher Education 21, and Greening Campuses have developed a range of tools and questionnaires that aim to assist universities to evaluate sustainability efforts and has been distributed widely (ULSF, 2009). In an evaluation of institutional assessment tools Shirberg (2002) notes that the majority of these tools are designed 
to assist institutions in strategic planning by identifying issues and methods to set and achieve sustainability goals, yet do not offer the ability to make comparisons between universities. At the same time however, whilst supporting the development of a universal tool, Shirberg questions whether universal tools, and particularly those that enable ranking, may miss the contextual complexities of specific institutions. The single institution focus is continued in Chambers (2009) $7 \times 4$ matrix that aims to assist universities to identify areas of strength and weakness and also operate as a planning tool. Chamber's tool draws on Calder and Clugston's (2003) critical dimensions, and considers them according to internal and external impacts, and taking into account both current and future consequences. However this tool is not designed to enable comparison across universities, and as of yet has not been applied in published research. Wright $(2006,2010)$ has applied a Delphi study approach to both explore university presidents' conceptualisations of sustainability in a cross-institutional study, as well as to develop an implementation plan within a single university. However, it remains clear that there is a heavy focus on planning and very limited focus on taking action and following through on plans. Indeed, of the suggestions outlined in Table 1, only Leal Fihlo (2009a) identifies the need to take action in relation to the challenges. Consequently there is a need for a framework to guide behaviour change across university campuses. In order to address this void this study has applied Brennan and Binney's 9Ps social marketing framework to investigate the implementation of sustainability across a range of universities. This framework highlights the stages of sustainability implementation by the organisation from identifying the guiding philosophy to a fully embedded sustainability program. As suggested by Leal Fihlo (2009a) many institutions have a planned implemtation program however, there are doubts that these plans are delivering fully embedded sustainabilty programs. This study aims to address this void in the the literature. 


\section{Methodology}

A qualitative phase of research, comprising in-depth interviews and focus groups, was used to develop the quantitative instrument for data collection. In-depth interviews were conducted with university staff whose involvement with environmental sustainability at their respective universities. This included teaching, researching and implementing sustainability practices. Discussions were guided by the elements described in Table 1 (The 9Ps framework for environmental action in universities). Using the principles of scale development suggested by De Vellis (2003), after a literature review, a pool of items was developed and discussed with an expert panel of people from four Australian universities. These people were senior members of staff responsible for sustainability operations and initiatives in their universities. Subsequently, a focus group of 10 university employees discussed the draft questionnaire; these participants were not involved in implementing sustainability and were therefore useful informants in terms of content validity, especially in relation to behavioural expectations and institutional performance. The participants were from different universities in order to ensure a range of views were available. The outcome of the focus group was a shorter and more semantically consistent set of items. Using the multi-trait-multi-method approach to validation (Campbell \& Fiske, 1959), related items were grouped in sets of three items to ensure that variations could be identified and results triangulated.

The draft questionnaire was then pre-tested on a sample of 20 participants. This confirmed that the instrument was ready for use. The final survey instrument used a 7 point Likert scale and comprised of a battery of 27 items relating to expectations and performance of 
sustainability attributes. Ethics approval was obtained and the instrument was emailed to all members of ACTS in the 27 member universities. Those surveyed were involved in environmental sustainability change management across a range of universities. The questionnaires from the online survey were downloaded, checked for completeness and accuracy and the data were entered and prepared for analysis. Data analysis including descriptive statistics, ANOVA, factor analysis and Gap analysis to determine the relationships between 'importance' and 'performance' of the behaviours under investigation was undertaken. The internal-consistency method was employed to test the reliability of the survey instrument utilising the Cronbach's alpha coefficient. Previous studies recommend the Cronbach's alpha measurement when assessing internal consistency of measurement items (Hair et al., 2006). Cronbach's alphas for the nine factors ranged from $0.73-0.96$, which is acceptable in exploratory research, that is, 0.60 or greater, indicating an admissible level of internal consistency (Hair et al., 2006).

In fact, this study has a focus on Importance Performance Analysis (IPA). IPA was utilised as a method of analysing information about sustainability behaviours in this research due to its clear results and informing various management decisions, including reallocation of resources (Oh 2000). IPA is based on the mean performance and mean importance gained from surveyed respondents for a number of attributes or characteristics of a product or service. The decision to use IPA was partly based on the arguments presented by Taplin (2012). IPA is a popular, low-cost, easily understood way to arrange information about the attributes of a product or service and provide management strategies for a business to set priorities for potential change. Oh, (2000 p.617) suggests 
that this method of analysis has gained popularity among researchers for its "simplicity and ease of application".

In addition, Gap Analysis was also used. Gap analysis is a type of benchmarking, with performance being measured against importance. The importance performance gap was produced by subtracting the importance score from the performance score (Taplin, 2011).

\section{Results and discussion}

Responses 55 responses were received and these represented 25 of the 27 member universities of ACTS and these data were used for analysis as discussed above in the methodology. Table 2 contains the reliability estimates for each of the 9Ps, the means for the perceived Importance and Performance of each item and the Gap analyses for each construct. There is also a scale mean of these measures for each construct. These results provide information on the perceived importance and whether or not the university adequately undertaken this type of activity in support of sustainability. 
Table 2. The 9Ps of Institutional behaviours with regard to the environment

\begin{tabular}{|c|c|c|c|c|c|c|}
\hline The Nine Ps & $\begin{array}{l}\text { Cronbach } \\
\text { alpha }\end{array}$ & $\begin{array}{l}\text { Item } \\
\text { no. }\end{array}$ & Items & Importance & Performance & $\begin{array}{c}\text { Difference } \\
\text { (Gap } \\
\text { analysis) }\end{array}$ \\
\hline Philosophy & .77 & $\begin{array}{l}1.1 \\
1.2 \\
1.3\end{array}$ & $\begin{array}{l}\text { A statement of commitment to environmental issues in } \\
\text { any planning or strategy documents } \\
\text { Indicative principles of behaviour in relation to the } \\
\text { environment are readily available } \\
\text { A clear set of objectives in relation to environmental } \\
\text { issues }\end{array}$ & $\begin{array}{l}5.75 \\
5.80 \\
6.11\end{array}$ & $\begin{array}{l}5.07 \\
3.80 \\
4.70\end{array}$ & $\begin{array}{l}2.0 \\
1.41\end{array}$ \\
\hline Scale mean & & & & 5.89 & $4.52^{*}$ & 1.37 \\
\hline Policy & .88 & $\begin{array}{l}2.1 \\
2.2 \\
2.3\end{array}$ & $\begin{array}{l}\text { An easily understood and readily available policy } \\
\text { An environmental action plan } \\
\text { Both a Policy and a System }\end{array}$ & $\begin{array}{l}5.52 \\
6.23 \\
5.74\end{array}$ & $\begin{array}{l}.34 \\
4.66 \\
3.45\end{array}$ & $\begin{array}{l}1.18 \\
1.57 \\
2.29\end{array}$ \\
\hline \multicolumn{4}{|l|}{ Scale mean } & 5.83 & $4.15^{*}$ & 1.68 \\
\hline Process & .76 & 3.1 & $\begin{array}{l}\text { Demonstrated initiatives in relation to environmental } \\
\text { issues } \\
\text { Measurement of effectiveness in relation to } \\
\text { environmental issues } \\
\text { A distributed set of expected behaviours for individuals } \\
\text { to do that relate to environmental issues (e.g., turning } \\
\text { off lights, printing emails) }\end{array}$ & $\begin{array}{l}6.33 \\
5.98\end{array}$ & $\begin{array}{l}4.28 \\
3.50\end{array}$ & $\begin{array}{l}2.05 \\
2.48\end{array}$ \\
\hline
\end{tabular}




\begin{tabular}{|c|c|c|c|c|c|c|}
\hline The Nine Ps & $\begin{array}{l}\text { Cronbach } \\
\text { alpha }\end{array}$ & $\begin{array}{l}\text { Item } \\
\text { no. }\end{array}$ & Items & Importance & Performance & $\begin{array}{c}\text { Difference } \\
\text { (Gap } \\
\text { analysis) }\end{array}$ \\
\hline \multicolumn{4}{|l|}{ Scale mean } & 6.20 & $4.25 *$ & 1.95 \\
\hline Procedures & .83 & $\begin{array}{l}4.1 \\
4.2 \\
4.3\end{array}$ & $\begin{array}{l}\text { An environmental management system (set of processes } \\
\text { and procedures) } \\
\text { Environmental sustainability is included in new staff } \\
\text { induction } \\
\text { A clear set of steps designed to achieve the various } \\
\text { environmental policies }\end{array}$ & $\begin{array}{l}6.23 \\
5.98\end{array}$ & $\begin{array}{l}3.23 \\
3.09 \\
3.64\end{array}$ & $\begin{array}{l}3.14 \\
2.34\end{array}$ \\
\hline \multicolumn{4}{|l|}{ Scale mean } & 5.92 & $3.32 *$ & 2.60 \\
\hline Promotion & .96 & 5.1 & $\begin{array}{l}\text { Regular internal communication about environment } \\
\text { issues (e.g., emails, web updates, e-news) } \\
\text { Regular reporting of the outcome of environmental } \\
\text { initiatives } \\
\text { Regular advertising of the successes in dealing with } \\
\text { environmental issues (e.g., printed materials, posters } \\
\text { placement, etc.) }\end{array}$ & $\begin{array}{l}6.00 \\
6.05\end{array}$ & $\begin{array}{l}4.24 \\
4.26\end{array}$ & $\begin{array}{l}1.76 \\
1.79\end{array}$ \\
\hline \multicolumn{4}{|l|}{ Scale mean } & 6.02 & $4.09 *$ & 1.93 \\
\hline People & .84 & $\begin{array}{l}6.1 \\
6.2\end{array}$ & $\begin{array}{l}\text { Appointment of environmental champions } \\
\text { Reward and recognition of environmental actions taken } \\
\text { by individuals } \\
\text { Support for people undertaking environmental activities } \\
\text { (e.g., empowering activism, time off, monetary } \\
\text { reimbursement) }\end{array}$ & $\begin{array}{l}5.81 \\
5.62 \\
5.07\end{array}$ & $\begin{array}{l}3.74 \\
3.02 \\
2.57\end{array}$ & $\begin{array}{l}2.07 \\
2.6 \\
2.5\end{array}$ \\
\hline
\end{tabular}




\begin{tabular}{|c|c|c|c|c|c|c|}
\hline The Nine Ps & $\begin{array}{l}\text { Cronbach } \\
\text { alpha }\end{array}$ & $\begin{array}{l}\text { Item } \\
\text { no. }\end{array}$ & Items & Importance & Performance & $\begin{array}{c}\text { Difference } \\
\text { (Gap } \\
\text { analysis) }\end{array}$ \\
\hline \multicolumn{4}{|l|}{ Scale mean } & 5.50 & $3.11^{*}$ & 2.39 \\
\hline Policing & .73 & 7.1 & $\begin{array}{l}\text { Regular audits of environmental sustainability activities } \\
\text { Enforcement of breaches of the environmental policies } \\
\text { of the organisation } \\
\text { Protection from consequences for people who make } \\
\text { complaints about environmental issues within the } \\
\text { organisation }\end{array}$ & $\begin{array}{l}5.26 \\
5.64\end{array}$ & $\begin{array}{l}2.45 \\
2.90\end{array}$ & $\begin{array}{l}2.81 \\
2.74\end{array}$ \\
\hline \multicolumn{4}{|l|}{ Scale mean } & 5.56 & $3.02 *$ & 2.54 \\
\hline Phollow up & .83 & 8.1 & $\begin{array}{l}\text { Closed loop reporting of environmental issues (e.g., } \\
\text { issues are addressed and the outcomes are reported to } \\
\text { senior management) } \\
\text { Future strategy development in relation to the outcomes } \\
\text { of the measures } \\
\text { People are required to complete professional } \\
\text { development in relation to environmental sustainability } \\
\text { as well as other training (e.g., OH\&S, Trade Practices } \\
\text { Compliance, Privacy Act, etc. }\end{array}$ & 6.00 & 3.72 & 1.72 \\
\hline \multicolumn{4}{|l|}{ Scale mean } & 5.77 & $3.43 *$ & 2.34 \\
\hline Persevere & .77 & 9.1 & $\begin{array}{l}\text { Long term (greater than } 5 \text { years) goals and strategies in } \\
\text { relation to environmental issues } \\
\text { Any initiatives that are implemented are given a long } \\
\text { term budget and lasting organisational support (greater }\end{array}$ & 6.49 & 3.79 & 2.23 \\
\hline
\end{tabular}




\begin{tabular}{|l|l|l|l|c|c|c|}
\hline The Nine Ps & Cronbach & $\begin{array}{l}\text { Item } \\
\text { no. } \\
\text { alpha }\end{array}$ & Items & Importance & $\begin{array}{c}\text { Performance } \\
\text { Difference } \\
\text { (Gap } \\
\text { analysis) }\end{array}$ \\
\hline & 9.3 & $\begin{array}{l}\text { Investment in relation to environmental issues is } \\
\text { indicated in strategic plans, departmental budget, staff } \\
\text { deployment and secondment, etc. }\end{array}$ & 6.43 & 3.86 & 2.57 \\
\hline Scale mean & & & 6.31 & $3.86^{*}$ & 2.45 \\
\hline
\end{tabular}


In general, Table 2 shows that each of the items is considered to be of high importance and therefore are essential to ensuring that there is a behaviour change towards sustainability in the university campuses. The scale mean show each construct is above 5.0 on a seven point scale and many are close to or exceed six indicating their perceived importance. Also, and of concern is that Table 2 shows that these important items are not being adequately practiced on university campuses. The scale mean for performance is a great deal lower for each measure with a mean of four or less and all are significantly lower at the 0.05 level (ANOVA). Further, the Gap analysis shows five of the nine constructs have a mean difference of two or greater which emphasizes the crucial difference between what is considered to be important and what is actually being practiced.

\section{Measures of importance}

Overall this shows that financial support, planning, communicating change, staff training, and action plans in place were seen as being of high importance and necessary for successful implementation of sustainability. This is demonstrated by the measures of items in Table 2 and Table 3 , having a score of six or greater for importance. The top rated items are listed in Table 3. These important items relate to 'budgetary support' (6.49), 'strategic planning' (6.43), 'measurement of effectiveness' (6.33), 'demonstrated initiatives'(6.29), 'staff induction' (6.23) and an 'environmental action plan' (6.23). 
Table 3. The most important items nominated by participants.

\begin{tabular}{|c|l|c|}
\hline & \multicolumn{1}{|c|}{ Item } & \multicolumn{1}{|c|}{} \\
\hline 9.2 & $\begin{array}{l}\text { Any initiatives that are implemented are given a long term budget and } \\
\text { lasting organizational support (greater than 12 months) }\end{array}$ & 6.49 \\
\hline 9.3 & $\begin{array}{l}\text { Investment in environmental issues is indicated in strategic plans, } \\
\text { departmental budgets, staff deployment and secondment and so on }\end{array}$ & 6.43 \\
\hline 3.2 & Measurement of effectiveness in relation to environmental issues & 6.33 \\
\hline 3.1 & Demonstrated initiatives in relation to environmental issues & 6.29 \\
\hline 4.2 & Environmental sustainability is included in the new staff induction & 6.23 \\
\hline 2.2 & An environmental action plan & 6.23 \\
\hline
\end{tabular}

In particular Table 3 shows a focus on institutional factors that facilitate or hinder environmental sustainability. For example, the most important items are budget allocation and investment, indicating that any financial constraints are likely to take precedence over other items.

\section{Sustainability behaviours being performed}

While many items that were considered as being important for sustainability they were not being widely practiced. This seems somewhat surprising considering that the participant completing the survey likely to be involved in sustainability within their university.

Table 4. The lowest performance items nominated by participants.

\begin{tabular}{|c|l|c|}
\hline No & \multicolumn{1}{|c|}{ Item } & \multicolumn{1}{|c|}{} \\
\hline 8.3 & $\begin{array}{l}\text { People are required to complete Professional Development in relation to } \\
\text { environmental sustainability as well as other training (e.g., OH\&S, Trade } \\
\text { Practices compliance, Privacy Act, etc.) }\end{array}$ & 2.44 \\
\hline 7.2 & Enforcement of breaches of the environmental policies of the organization & 2.45 \\
\hline 6.3 & $\begin{array}{l}\text { Support for people undertaking environmental activities (e.g., time off, } \\
\text { empowering activism) }\end{array}$ & 2.57 \\
\hline 7.3 & $\begin{array}{l}\text { Protection from consequences for people who make complaints about } \\
\text { environmental issues within the organization }\end{array}$ & 2.9 \\
\hline
\end{tabular}




\begin{tabular}{|c|l|c|}
\hline 6.2 & $\begin{array}{l}\text { Reward and recognition of environmental actions taken by individuals (e.g., } \\
\text { awards for excellence) }\end{array}$ & 3.02 \\
\hline 4.2 & Environmental sustainability is included in the new staff induction & 3.09 \\
\hline
\end{tabular}

Table 4 highlights items with the lowest performance levels. It could be noted that many of these relate to the individual's behaviour in the organisation. Staff development (2.44) and staff induction programs (3.09) in relation to environmental sustainability are generally not including aspects designed to equip staff with the knowledge and skills to foster behaviour change. Breaches of policies (2.45) have a low performance level which would suggest that there are no apparent consequences for non-adoption. Other items with low levels include support for people (2.57), protection for those who speak up about environmental issues (2.90), and reward and recognition to encourage individual action (3.02) are also not at high levels of performance.

\section{Conclusion and implications}

There are a diversity of actions that institutions of higher education can implement to make the transition towards the university-wide adoption as highlighted previously Krizek et al. (2012). This study has identified a range of these activities that have been identified as being 'important' and provided an estimate of the level of importance as judged by those involved with implementing sustainability at a majority of Australian universities.

In addition, the study has also provided an estimate of the 'performance' level of these activities across these institutions. It is noted that many of the behaviours that are assessed as being important have not been adequately implemented as shown by the results of the gap analysis. It is contended that, in general, to optimise the overall level of sustainability adoption, important sustainability practices that are not being performed should be implemented as a matter of 
priority by those charged with implementing and embedding environmental sustainability across the campus.

The study also highlights that environmental sustainability is generally in place at the 'philosophical', 'policy', and "promotional' level of the 9Ps; but is not being adequately implemented through the 'processes', 'procedures', and 'people', or being satisfactorily maintained through 'policing', 'phollowup', and 'preserving' with the sustainable practices. While we concur that a founding "philosophical" approach to the intended changes is required (Wright, 2010), it is highlighted that there are other important issues to be considered. This is in agreement with the findings of Jones (2012) and Lee, et al. (2013) who noted that there is often a disconnect between the espoused philosophy of sustaining the biosphere and implementation of adequate processes.

While this study has provided guidelines for practitioners and researchers involved in university-wide adoption of sustainability, it also identifies that further research is required to uncover why these specific practices and procedures that have been identified as being of high importance, are not being implemented. Some of the possible reasons for this may originate from lack of encoragment from management to "finish the job" as suggested by the relatively lower level of implementation from 'processess' through to 'perservering'. While it may be a result of limited resourcing as management have developed a philosphy, put plans in place and believe that they have completed the task. The 9Ps Framework, as suggested by the supporting referenced articles, provides a guide to achieve widespread 'embedded' sustainable practices across the University campus. If the task is not being completed then the task remains to develop 
a deeper understanding of the specific reasons for the partially completed implementation. It is recommended that a further study to identify the barriers to behaviour change that will facilitate the widespread adoption of sustainable practices. Again the 9Ps Framework could be used to facilitate a systematic analysis of the specific impediments for each stage of the implementation process. As this study has involved a majority of the member universities of ACTS this group could be approached to become involved in specific case studies and this would overcome a limitation of this study that it has used a survey methodology.

Finally, it is suggested that these guidelines may be transferrable and could provide direction for changes for non-university organisations. As discussed by Sawang and Kivits (2014) many in the community look to universities to provide a leadership role in relation to sustainability. This study suggests that the 9Ps Framework offers guidelines for effective adoption of sustainable practices in other organisations. 


\section{References}

Beattie, A. (2014). Cost-Benefit Analysis of Food-Waste Composting Program at UMM. Scholarly Horizons: University of Minnesota, Morris Undergraduate Journal, 1(1), 1.

Benjamin, L. (2013). Incentive Deserts: The Opportunities and Barriers to Solar PV Financing at UCLA http://www.aashe.org/files/resources/studentresearch/2009/incent_dsrts_lbenjamin1.pdf.

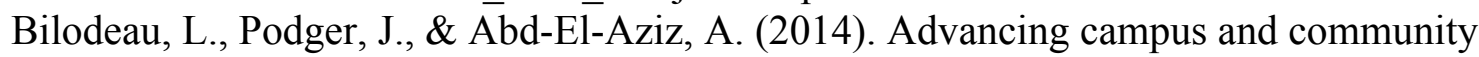
sustainability: strategic alliances in action. International Journal of Sustainability in Higher Education, 15(2), 4-4.

Brennan, L., \& Binney, W. (2011a). Making sustainability a behaviour in the tertiary sector. Paper presented at the 2nd World Social Marketing Conference, Dublin Ireland.

Brennan, L., \& Binney, W. (2011b). Making sustainability a behaviour, not a belief. Paper presented at the the 10th International Conference of Australasian Campuses Towards Sustainability, RMIT Melbourne, Victoria.

Brennan, L., Binney, W., Parker, L., Aleti Watne, T., \& Nguyen, D. H. H. (2014). Behaviour change models: theory and application for social marketing. Cheltenham, UK Edward Elgar.

Campbell, D. T., \& Fiske, D. W. (1959). Convergent and discriminant validation by the multitrait-multimethod matrix. Psychological Bulletin, 56, 81-105.

Cebrián, G., Grace, M., \& Humphris, D. (2013). Organisational learning towards sustainability in higher education. Sustainability Accounting, Management and Policy Journal, 4(3), 285-306.

Chambers, D. (2009). Assessing and planning for environmental sustainability: A framework for institutions of higher education. In W. Leal Filho (Ed.), Sustainability at universities: Opportunities, challenges and trends (pp. 287-297). Frankfurt: Peter Lang.

Clugston, R. M. (2000). Introduction. In W. Leal Filho (Ed.), Sustainability and university life (pp. 11-18). Frankfurt: Peter Lang.

Clugston, R. M., \& Calder, W. (2000). Critical dimesions of sustainability in higher education. In W. Leal Filho (Ed.), Sustainability and university life (pp. 31-46). Frankfurt: Peter Lang.

De Vellis, R. F. (2003). Scale Development: Theory and Applications (2nd ed. Vol. 26). Thousand Oaks, CA: Sage Publications. Djordjevic, A., \& Cotton, D. R. E. (2011). Communicating the sustainability message in higher education institutions. International Journal of Sustainability in Higher Education, 12(4), 381-394.

Dobson, A., Quilley, S., \& Young, W. (2010). Sustainability as competitive advantage in higher education in the UK. International Journal of Environment and Sustainable Development, 9(4), 330-348.

Gordon, R. (2013). New ideas-Fresh thinking: Towards a broadening of the social marketing concept? Journal of Social Marketing, 3(3), 1-1.

Halifax (1991). Halifax Action Plan for Universities of 1991 (http://www.iisd.org/educate/declarat/halifax.htm)

Hair, J.F., Black, W.C., Anderson, R.E.. Tatham, R.L. (2006) Multivariate Data Analysis. (Katie Stevens Ed. 6th ed.). New Jersey 07458: Pearson Education Inc,. 
Hoover, E., \& Harder, M. K. (2014). What lies beneath the surface? The hidden complexities of organizational change for sustainability in higher education. Journal of Cleaner Production.

Hovell, M. F., \& Hughes, S. C. (2009). The behavioral ecology of secondhand smoke exposure: A pathway to complete tobacco control. Nicotine \& Tobacco Research, 11(11), 12541264.

Hovell, M. F., Wahlgren, D. R., \& Gehrman, C. A. (2002). The behavioral ecological model. Emerging Theories in Health Promotion Practice and Research. Strategies for Improving Public Health, 347-385.

Jones, D. R. (2012). Looking through the "greenwashing glass cage" of the green league table towards the sustainability challenge for UK universities. Journal of Organizational Change Management, 25(4), 630-647.

Karlin, B., Davis, N., \& Matthew, R. (2013). GRASP: Testing an Integrated Approach to Sustainability Education. Journal of Sustainability Education.

Krizek, K. J., Newport, D., White, J., \& Townsend, A. R. (2012). Higher education's sustainability imperative: how to practically respond? International Journal of Sustainability in Higher Education, 13(1), 19-33.

Kyoto (1993). Kyoto Declaration of the International Association of Universities of 1993 (http://archive.www.iau-aiu.net/sd/sd_dkyoto.html).

Leal Filho, W. (2009a). Sustainability at universities - Opportunities, challenges and trends. In W. Leal Filho (Ed.), Sustainability at universities: Opportunities, challenges and trends (pp. 313-320). Frankfurt: Peter Lang.

Leal Filho, W. (Ed.). (2000). Sustainability and university life. New York: Peter Lang.

Leal Filho, W. (Ed.). (2009b). Sustainability at universities - Opportunities, challenges and trends. Frankfurt: Peter Lang.

Leal Filho, W., \& Carpenter, D. (Eds.). (2006). Sustainability in the Australiasian university context. Frankfurt: Peter Lang.

Lee, K.-H., Barker, M., \& Mouasher, A. (2013). Is it even espoused? An exploratory study of commitment to sustainability as evidenced in vision, mission, and graduate attribute statements in Australian universities. Journal of Cleaner Production, 48, 20-28.

McMillin, J., \& Dyball, R. (2009). Developing a whole-of-university approach to educating for sustainability linking curriculum, research and sustainable campus operations. Journal of Education for Sustainable Development, 3(1), 55-64.

Moganadas, S. R., Corral-Verdugo, V., \& Ramanathan, S. (2013). Toward systemic campus sustainability: gauging dimensions of sustainable development via a motivational and perception-based approach. Environment, development and sustainability, 15(6), 1443 1464.

Orr, D. W. (2000). Transformation or irrelevance: The challenge of academic planning for environmental education in the 21 st century. In W. Leal Filho (Ed.), Sustainability and university life. Frankfurt: Peter Lang.

Posner, S. M., \& Stuart, R. (2013). Understanding and advancing campus sustainability using a systems framework. International Journal of Sustainability in Higher Education, 14(3), 264-277.

Radford, A. (2012). A Critical Assessment of University Sustainable Development Policy: A Gloucestershire Case Study. Earth \& E-nvironment, 8, 210-241. 
Ralph, M., \& Stubbs, W. (2014). Integrating environmental sustainability into universities. Higher Education, 67(1), 71-90.

Sawang, S., \& Kivits, R. A. (2014). Greener workplace: understanding senior management's adoption decisions through the Theory of Planned Behaviour. Australasian Journal of Environmental Management, 21(1), 22-36.

Sharp, L. (2002). Green campuses: The road from little victories to systemic transformation. International Journal of Sustainability in Higher Education, 3(2), 128-145.

Shriberg, M. (2002). Institutional assessment tools for sustainability in higher education: Strengths, weaknesses, and implications for practice and theory. International Journal of Sustainability in Higher Education, 3(3), 254-270.

Spira, F., Tappeser, V., \& Meyer, A. (2013). Perspectives on Sustainability Governance from Universities in the USA, UK, and Germany: How do Change Agents Employ Different Tools to Alter Organizational Cultures and Structures? Sustainability Assessment Tools in Higher Education Institutions (pp. 175-187): Springer.

Sylvestre, P., McNeil, R., \& Wright, T. (2013). From Talloires to Turin: A Critical Discourse Analysis of Declarations for Sustainability in Higher Education. Sustainability, 5(4), 1356-1371.

Talloires (1990). Talloires Declaration of University Leaders for a Sustainable Future of 1990 (http://www.ulsf.org/pdf/TD.pdf)

ULSF. (2009). Sustainability assessment questionnaire for colleges and universities. Wayland, MA: Association of University Leaders for a Sustainable Future.

United Nations (2005). United Nations Decade of Education for Sustainable Development (http://www.desd.org/).

United Nations World Commission on the Environment and Development (Brundtland Commission). (1987). Our Common Future: United Nations.

Wilson Jr, T. W. (1973). Creating Mechanisms for International Environmental Action: Requirements and Response. Stanford Journal of International Studies, 8, 113-122.

Wright, T. (2002). Definitions and frameworks for environmental sustainability in higher education. International Journal of Sustainability in Higher Education, 3(3), 203-220.

Wright, T. (2006). Giving "teeth" to an environmental policy: A Delphi Study at Dalhousie University. Journal of Cleaner Production, 14, 761-768.

Wright, T. (2010). University presidents' conceptualisations of sustainability in higher education. International Journal of Sustainability in Higher Education, 11(1), 61-73. 